Journal of Animal and Veterinary Advances 11 (17): 3073-3075, 2012

ISSN: $1680-5593$

(C) Medwell Journals, 2012

\title{
A Human Case Report of Diphyllobothrium latum at Shanghai, China
}

\author{
H. Li, S.H. Chen, Y.N. Zhang, L. Ai and J.X. Chen \\ National Institute of Parasitic Disease, Chinese Center for Disease Control and Prevention, \\ Key Laboratory of Parasite and Vector Biology, Ministry of Health, \\ WHO Collaborating Center of Malaria, Schistosomiasis and Filariasis, \\ 200025 Shanghai, The People's Republic of China
}

\begin{abstract}
Fish tapeworm (Diphyllobothrium species) are endemic in many parts of the word, the commonest species being Diphyllobothrium latum. Human are the main definitive host of D. latum and the majority of individuals harbouring the parasite are asymptomatica. In this report, researchers describe a case of $D$. latum infection founded on routine detection of eggs in fecal. After the whole cestode gotten, PCR Molecular Method had been done for identification.
\end{abstract}

Key words: Diphyllobothrium latum, eggs, cestode, PCR, paracite, China

\section{INTRODUCTION}

Human diphyllobothriosis, a worldwide fish-borne zoonosis, caused by tapeworms of the genus Diphyllobothrium Cobbold, 1858 (Cestoda: Diphyllobothriidea) with complex life cycles involved in two intermediate hosts (copepod or fish) and a definitive host (humans or other piscivorous mammals and aquatic birds) (Jeon et al., 2009). Infection occurs through the consumption of raw or undercooked fish harboring plerocercoid larvae and often ignored until the excretion of proglottids in stools. Symptoms include various minor digestive problems occurring a few weeks after infection (mostly nausea, diarrhea and abdominal pain), less commonly, prolonged or heavy infections can result in a pernicious anemia (Lee et al., 1989; Wu, 2005).

The identification of Diphyllobothrium tapeworms by physicians and medical laboratories is generally based on the morphological observation eggs and proglottids of adult worms (Jeon et al., 2009). Morphoanatomical criteria allow identification to the genus level but are not reliable to assess species identity because the different taxa are extremely similar to one another and species differentiation relies on characteristics of the scolex or the genital apparatus observed on mature proglottids which are often unavailable during human infections (Stunkard, 1965). Thus, molecular methods have been recommended (Wicht et al., 2010; Usmanova and Kazakov, 2010; Mercado et al., 2010).

\section{CASE REPORT}

A 30 years old woman with a history of stomachache, abdominal distension, diarrhea and excerting white living proglottid, went to Xinrui Medical Centre to detect at Dec. 3rd, 2011. From 2008-2011, the patient had spent most of time in Shang hai and occasional vacation in Austrilia, France, Thailand, Japan, USA and some rural areas in China. During these 3 years, she had consumed raw fish (both sea fish and fresh water fish) in Japan and China. After $4 \mathrm{~h}$ by taking betel nut and pumpkin seed decoction and $\mathrm{MgSO}_{4}$ solution for catharsis orally a whole cestode had been excerted successfully.

The cestode had been took to the laboratory of the National Institute of Parasitic Diseases, Chinese Center for Disease Control and Prevention to identify by morphology and molecular. The length of the cestode was nearly $5 \mathrm{~m}$ and the width was $1 \mathrm{~cm}$ with scolex as spoon like (Fig. 1). Morever, there was also deep cannelure in scolex and the width of mature proglottid was longer than the length evidently (Fig. 2). After dyed by coccinellinq and microscopy of rosette-shape uterus like could be observed in the middle of their gravid proglottids. Eggs characteristic of $D$. latum with yellowish brown color and size of 61.0-65.3 $\times 41.7-46.1 \mu \mathrm{m}$ and display a small knob or abopercular on the opposite end of a lid-like opening or operculum which may be in conspicuous (Fig. 3).

The DNA of mature proglottids has been extracted with SDS/proteinase $\mathrm{K}$ treatment, column-purified (Wizard ${ }^{\boxplus}$ SV Genomic DNA Purification System, Promega)

Corresponding Author: J.X. Chen, National Institute of Parasitic Disease, Chinese Center for Disease Control and Prevention, Key Laboratory of Parasite and Vector Biology, Ministry of Health, WHO Collaborating Center of Malaria, Schistosomiasis and Filariasis, 200025 Shanghai, The People's Republic of China 
Table 1: Primers used in this report

\begin{tabular}{lllr}
\hline Genes & Primers & Sequences & The length of product (bp) \\
\hline Coxl & JB6 (common primer) & 5'-GATAGTAAGGGTGTTGA-3' & 650 \\
& JB5R (common primer) & 5'-CAAGTATCRTGCAAAATATTATCAAG-3' & \\
Coxl & D1/Dn-1805F (specific primer) & 5'-CAGTGGGAATGGTGCTTGTAATGT-3' & 428 \\
& Dl-2211R (specific primer) & 5'-TAACCTTTACTTATAACTACT-3' & \\
\hline
\end{tabular}

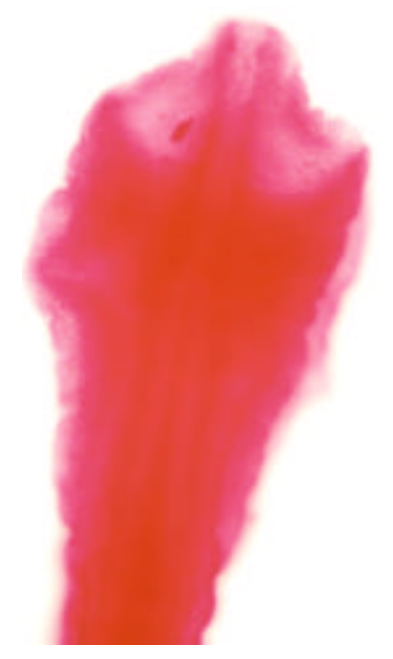

Fig. 1: Scolex of Diphyllobothrium latum (10 times)

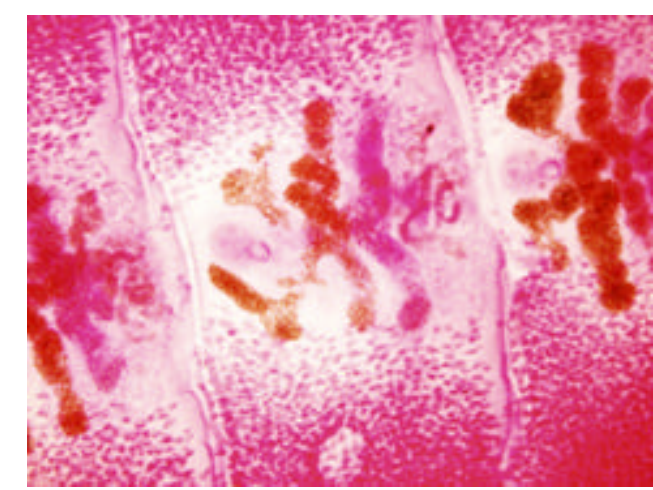

Fig. 2: Gravid proglottid of Diphyllobothrium latum (4 times)

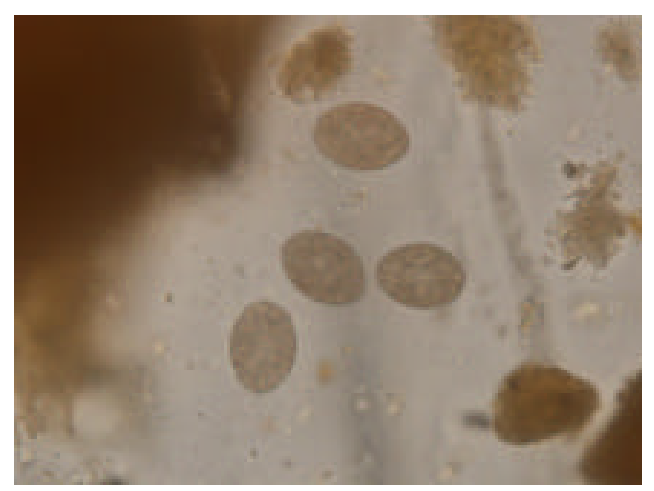

Fig. 3: Eggs of Diphyllobothrium latum (40 times)

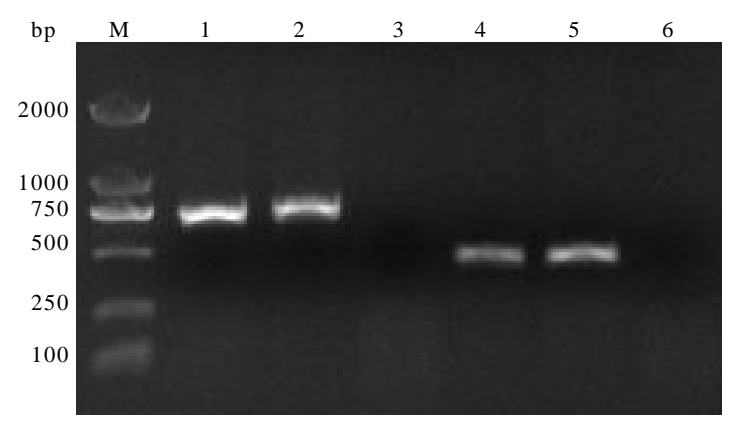

Fig. 4: Agarose gel electrophoresis of pcoxl PCR products of representative Diphyllobothrium latum from patients. Lanes 1, 2 represent the PCR results of common primers, Lane 4, 5 reprents the PCR results of specific primers. Lanes 3, 6 represents negative control. $\mathrm{M}$ represents a DNA size marker (ordinate values in bp)

(Ai et al., $2010 \mathrm{a}, \mathrm{b}$ ). Then, the Polymerase Chain Reaction (PCR) Method also had been used in the identification by the primers to amply part of $\operatorname{cox} 1$ mitochondrial gene with common primers and specific primers (Table 1). PCR reactions $(25 \mu \mathrm{L})$ were performed in $2 \mathrm{mM}$ of $\mathrm{MgCl}_{2}$, $2.5 \mu \mathrm{M}$ of each primer, $2.5 \mu \mathrm{L} 10 \times \mathrm{rTaq}$ buffer, $0.2 \mathrm{mM}$ of each dNTPs, $1.25 \mathrm{U}$ of rTaq DNA polymerase (TAKARA) and $1 \mu \mathrm{L}$ of DNA sample in a thermocycler (Biometra) under the following conditions: after an initial denaturation at $94^{\circ} \mathrm{C}$ for $5 \mathrm{~min}$ then, $94^{\circ} \mathrm{C}$ for $30 \mathrm{sec}$ (denaturation); $55^{\circ} \mathrm{C}$ for $30 \mathrm{sec}$ (for common primers) and $60^{\circ} \mathrm{C}$ (for specific primers) (annealing); $72^{\circ} \mathrm{C}$ for $30 \mathrm{sec}$ (extension) for 35 cycles, followed by a final extension at $72^{\circ} \mathrm{C}$ for $5 \mathrm{~min}$. Control samples without genomic DNA was included in each amplification run and in no case were amplicons detected in the controls. Each amplicon $(3 \mu \mathrm{L})$ was examined by agarose gel electrophoresis to validate amplification efficiency (Fig. 4). Positive amplicons purified and sequenced using an ABI 377 automated DNA sequencer (using BigDye Terminator Chemistry) employing the same primers used in the PCR.

Then, the sequences were blasted in NCBI and the results could be founded at Table 2 and 3 . The results show that the cestode was identified as D. latum. 
Table 2: The blasted result of the sequences producing significant alignments using the common primers

\begin{tabular}{|c|c|c|c|c|c|c|c|}
\hline Accession & Description & $\begin{array}{l}\text { Maximum } \\
\text { score }\end{array}$ & $\begin{array}{l}\text { Total } \\
\text { score }\end{array}$ & $\begin{array}{c}\text { Query } \\
\text { coverage (\%) }\end{array}$ & E-value & $\begin{array}{l}\text { Maximum } \\
\text { ident (\%) }\end{array}$ & Links \\
\hline AB511963.1 & Diphyllobothrium latum mitochondrial coxI gene for cy tochrome COX & 1258 & 1258 & 98 & 0 & 99 & - \\
\hline AB510496.1 & Diphyllobothrium latum mitochondrial coxI gene for cy tochrome COX & 1258 & 1258 & 98 & 0 & 99 & - \\
\hline
\end{tabular}

Table 3: The blasted result of the sequences producing significant alignments using the specific primers

\begin{tabular}{llccccc}
\hline Accession & Description & $\begin{array}{c}\text { Maximum } \\
\text { score }\end{array}$ & $\begin{array}{c}\text { Total } \\
\text { score }\end{array}$ & $\begin{array}{c}\text { Query } \\
\text { coverage (\%) }\end{array}$ & $\begin{array}{c}\text { E-value } \\
\text { ident (\%) }\end{array}$ \\
\hline DO985706.1 & Diphyllobothrium latum mitochondrion, complete genome & 785 & 785 & 99 & 0 & 99 \\
AB269325.1 & Diphyllobothrium latum mitochondrial DNA, complete genome & 774 & 774 & 99 & 0 & 99 \\
AB268585.1 & Diphyllobothrium nihonkaiense mitochondrial DNA, complete genome & 547 & 547 & 99 & $2 \mathrm{e}-152$ & 90 \\
EF420138.1 & Diphyllobothrium nihonkciense mitochondrion, complete genome & 536 & 536 & 94 & $4 \mathrm{e}-149$ & 90 \\
\hline
\end{tabular}

\section{DISCUSSION}

The adult $D$. latum parasites in the small intestine of dog, cat and other carnivore. Human was also the definitive host without obvious symptom or $40 \%$ may have low B12 leveals but only 2\% devlop anacmia or nausea, vomit, diarrhea sometimes. This cestode mainly distribited in Europe, America and Asia. The infection rate was most high at Finland, Switzerland and Lithuania. Hitherto, there were 11 cases report about this disease with 9 cases inputting from former Soviet Union, American, Argentina and Japan. With the development and peoples living standard, raw and fresh fish will be more and more appreciated. So, the zoonic cesdode disease must be reconstruction and prevention.

\section{CONCLUSION}

In this research, the case has been diagnosized not only by morphplogy of the parasite but also by PCR Method to amply part of coxl gene and specific primers.

\section{ACKNOWLEDGEMENTS}

This research is supported in part by the Program for the International Development Research Centre, Canada (Project No. 105509-00001002), National S\&T Major Program (GrantNo. 2012ZX10004220, 2008ZX10004-001, 2008ZX10004-01 1,2009ZX10004-302 and 2009ZX1 0004201), National Key Technology R\&D Program (Grant No. 2008BAI56B03) and the Open Funds of the State Key Laboratory of Veterinary Etiological Biology, Lanzhou Veterinary Research Institute, Chinese Academy of Agricultural Sciences (Grant No. SKLVEB2009KFKT008, SKLVEB2010KFKT009, SKLVEB2011KFKT004 and SKLVEB2011KFKT010). The experiments comply with the current laws of the country in which the experiments were performed.

\section{REFERENCES}

Ai, L., C. Li, H.M. Elsheikha, S.J. Hong and J.X. Chen et al., 2010b. Rapid identification and differentiation of Fasciola hepatica and Fasciola gigantica by a loop-mediated isothermal amplification (LAMP) assay. Vet. Parasitol., 174: $228-233$.

Ai, L., S.J. Dong, W.Y. Zhang, H.M. Elsheikha and Y.S. Mahmmod et al., 2010a. Specific PCR-based assays for the identification of Fasciola species: Their development, evaluation and potential usefulness in prevalence surveys. Ann. Trop. Med. Parasitol., 104: 65-72.

Jeon, H.K., K.H. Kim, S. Huh, J.Y. Chai, D.Y. Min, H.J. Rim and K.S. Eom, 2009. Morphologic and genetic identification of Diphyllobothrium nihonkaiense in Korea. Kor. J. Parasitol, 47: 369-375.

Lee, S.H., J.Y. Chai, S.T. Hong, W.M. Sohn, S. Huh, E.H. Cheong and S.B. Kang, 1989. Seven cases of Diphyllobothrium latum infection. Seven cases of Diphyllobothrium latum infection. Korean. J. Parasitol, 27: 213-216.

Mercado, R., H. Yamasaki, M. Kato, V. Munoz, H. Sagua, P. Torres and D. Castillo, 2010. Molecular identification of the Diphyllobothrium species causing diphyllobothriasis in Chilean patients. Parasitol. Res., 106: 995-1000.

Stunkard, H.W., 1965. Variation and criteria for generic and specific determination of diphyllobothriid cestodes. J. Helminthol., 39: 281-296.

Usmanova, N.M. and V.I. Kazakov, 2010. The DL1 repeats in the genome of Diphyllobothrium latum. Parasitol. Res., 107: 449-452.

Wicht, B., T. Yanagida, T. Scholz, A. Ito, J.A. Jimenez and J. Brabec, 2010. Multiplex PCR for differential identification of broad tapeworms (Cestoda: Diphyllobothrium) infecting humans. J. Clin. Microbiol., 48: 3111-3116.

Wu, G.L., 2005. Human Parasitology. 3rd Edn., Peoples Medical Publishing House, Beijing, China, pp: 584-585. 